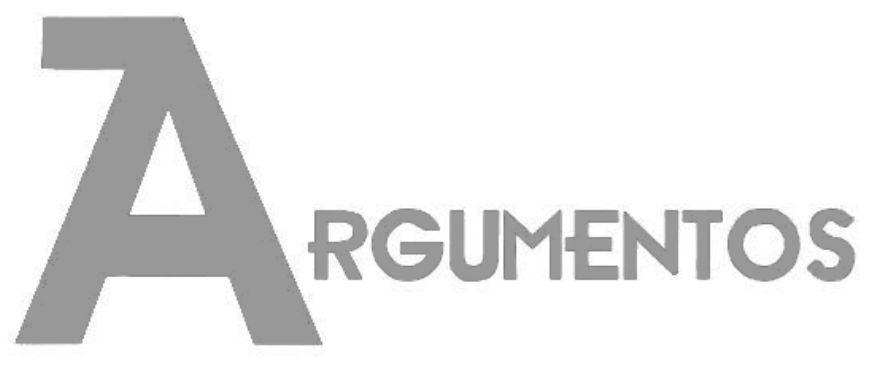

Vol. 18, n. 1, jan./jun. 2021 ISSN: 2527-2551 (online)

https://www.periodicos.unimontes.br/index.php/argumentos

\title{
Religiões Afro, desigualdade e discriminação étnico-racial
}

\author{
Rubens Alves da Silva ${ }^{1}$
}

Recebido em: 22/01/2020

Aprovado em: 08/02/2020

\begin{abstract}
Resumo: A diversidade das formas de expressões da cultura africana recriada em solo brasileiro na longa duração, é um tema que desde o século XIX intelectuais nacionais e estrangeiros se interessaram pelo estudo com intuito invariavelmente de explicar a problemática identitária e o desenvolvimento sociocultural do país. Os estudos do campo das oferecem elementos para uma reflexão crítica sobre discursos e imagens construídas sobre essa cultura, também descrita como afro-diaspórica, atentando para temática da desigualdade e discriminação étnico racial do negro na sociedade brasileira. Portanto, matriz africana ou afro-brasileiras, objetivando refletir a questão.
\end{abstract}

Palavras-chave: Religiões afro-brasileiras, desigualdade, discriminação étnico-racial.

\section{Religiones afro, desigualdad y discriminación étnico-racial}

Resumen: La diversidad de formas de expresión de la cultura africana recreada en suelo brasileño en el largo plazo, es un tema que desde el siglo XIX, intelectuales nacionales y extranjeros se han interesado en el estudio con el objetivo de explicar invariablemente los problemas de identidad y la socio- desarrollo cultural del país. Los estudios de campo ofrecen elementos para una reflexión crítica sobre los discursos e imágenes construidas sobre esta cultura, también descrita como afrodiaspórica, centrándose en el tema de la desigualdad racial y la discriminación étnica de los negros en la sociedad brasileña. Por tanto, matriz africana o afrobrasileña, con el objetivo de reflejar el tema.

Palabras-clave: Religiones afrobrasileñas, desigualdad, discriminación étnico-racial.

\section{Afro religions, inequality and ethnic-racial discrimination}

Abstract: The diversity of forms of expression of African culture recreated on Brazilian soil in the long term, is a theme that since the 19th century, national and foreign intellectuals have been interested in the study with the aim of invariably explaining the identity problems and the sociocultural development of the country. Studies in the field of elements for a critical reflection on 1 Professor Associado da Universidade Federal de Minas Gerais (UFMG), Brasil. E-mail:
rubssilva@gmail.com. ORCID: https://orcid.org/0000-0003-1516-0683. 
the discourses and images built on this culture, also descended as Afro-diasporic, focusing on the theme of racial inequality and ethnic discrimination of blacks in Brazilian society. Therefore, African or Afro-Brazilian matrix, aiming to reflect the issue.

Keywords: Afro-Brazilian religions, inequality, ethnic-racial discrimination.

\section{Introdução}

Escrever sobre a "desigualdade e discriminação étnico-racial" remete inevitavelmente o pensamento ao processo histórico da expansão mercantil que arrancou do continente africano inúmeras pessoas para escravização de sua força de trabalho nas terras do além-mar; levadas sem escolha ou querer para lugares onde sequer sabiam quão distantes estavam separadas de seus familiares e comunidade de origem.

Essa situação objetiva imposta a mulheres, homens e até crianças, no contexto da longa duração em solo das terras brasileiras coloniais e onde se exigiu, daqueles nossos antepassados da travessia, encontrar meios próprios para não se deixar levar pelo mal do banzo e sucumbir-se de vez; meios para manter a dignidade e o sentimento do valor que possuíam como qualquer outro ser humano...

Meios então que só poder-se-ia ser a criação dos espaços de tessitura dos laços de sociabilidade e onde, coletivamente e sem alarde, cultivar o sonho de liberdade imprescindível e energizante do ânimo de resistir e reexistir, sem receio de se perder de si mesmo, sozinho, pelos caminhos tortuosos do Novo Mundo - longe no além mar. Sendo estes meios senão outros que as invenções das culturas diaspóricas: as religiões, as irmandades, quilombos e capoeiragem, lócus da preservação de uma memória viva incorporada de saberes, conhecimentos e epistemes ancestrais africanas.

Neste ensaio cuja temática em foco é a desigualdade e discriminação étnicoracial, visando desenvolver a reflexão afim decidi revisitar estudos sobre as religiões afro-brasileiras.

\section{Entre "raça" e "cultura": uma leitura a contrapelo}

Os primeiros estudos sistemáticos sobre as religiões africanas no Brasil, como é sabido, surge em finais do século XIX, tendo como referência importante a produção do 
médico maranhense Nina Rodrigues (1862-1906), reconhecido como pioneiro da abertura desse campo de estudo e mesmo da antropologia no país. Nina Rodrigues era adepto das teorias racistas importadas da Europa e que influenciou fortemente o pensamento de proeminentes intelectuais brasileiros da época que, como ele próprio, compartilharam com seus escritos e críticas do debate em torno de um projeto de modernização e progresso nacional, colocando em pauta o "problema do negro". (SHWARCHS 1993; SKIDMORE, 1976). Confiante nos pressupostos das teorias racistas (inclusive já desacreditadas no meio científico europeu naquele período de transição de séculos), Nina Rodrigues era concorde com o ponto de vista da inferioridade racial do negro, reiterando essa convicção dele nos escritos sobre o código penal brasileiro e registros etnográficos da cultura negra no Brasil.

No livro As raças humanas e a responsabilidade penal no Brasil, publicada em 1894, Rodrigues discutiu a revisão do código penal brasileiro, advogando estabelecer-se instrumentos jurídicos diferenciado para negros e brancos no código penal brasileiro, a propósito do julgamento equilibrado de crimes cometido pelos primeiros. A justificativa para essa necessidade argumentada por Rodrigues consistia na avaliação "científica" dele da incapacidade de o negro assimilar integralmente os valores e as regras morais da civilização, dado à suposta inferioridade racial. Por isso, no entendimento dele, o negro era tendente à criminalidade.

Nessa obra Nina Rodrigues evidencia os pressupostos teóricos racistas que norteavam o pensamento dele e discute a questão da mistura racial no Brasil. Ele enxergava com pessimismo essa ocorrência e argumentou que o cruzamento de "raças superiores" (brancos) com "raças inferiores" (negros e indígenas), fatalmente levaria à "degeneração" racial. Por isso na avaliação dele o negro era um problema para o futuro da nação brasileira, cuja formação populacional se configurou pela mistura racial, isto é, a "mestiçagem". Portanto, o desejo frustrado de Nina Rodrigues era com a pureza de raça. Esse elemento que ele buscou encontrar no estudo das religiões nas religiões que definiu pela expressão "animismo fetichista" 2 .

\footnotetext{
${ }^{2}$ Como escreveu o antropólogo Sérgio Ferretti em resenha de homenagem aos cem anos da morte de Nina Rodrigues "Animismo e fetichista é a expressão, hoje preconceituosa, pela qual no século XIX, eram conhecidas as religiões dos chamados povos primitivos, hoje superada, juntamente com outros conceitos como totemismo." (FERRETTI, 2006, p.55).
} 
Nas obras, Animismo Fetichista dos Negros Bahianos ${ }^{3}$, publicado em 1896 e Africanos no Brasil, publicado em $1933^{4}$, pode-se apreender reiteração de Nina Rodrigues do ponto de vista dele da inferiorização racial do negro. Em Animismofetichista do negro baiano consiste em registro etnográfico produzido por Nina Rodrigues quase exclusivamente a partir da observação direta in locu, na visita a terreiros dos candomblés da Bahia, principalmente o Gantois. De maneira sistemática e detalhada ele mostrou como se organizava e funcionava os terreiros de candomblés na Bahia: o panteão dos orixás, a prática ritual, a hierarquia simbólica, a arquitetura e divisão interna do templo. Mencionou as disputas entre lideranças de terreiros e a relação dos terreiros com a sociedade envolvente - com destaque para censura por parte de eclesiásticos e a repressão pelo poder público.

Na segunda obra, Africanos no Brasil, ele estabelece o diálogo com uma vasta literatura, incluindo autores africanistas, discorrendo sobre as religiões fetichistas em África, eventos históricos, como as rebeliões protagonizadas por negros escravizados e a guerra do quilombo de Palmares, a distinção entre o contingente africano introduzido na Bahia, os sudaneses e no Rio de Janeiro e Pernambuco, de descrição linguística banto, a questão do sincretismo entre outros assuntos.

Na leitura dessas obras apreende-se que a motivação que levou Nina Rodrigues a empenhar-se no trabalho pioneiro, no Brasil, da etnografia dos terreiros de candomblés nagôs da Bahia, estava a vontade dele de comprovar cientificamente a suposição dele da inferioridade racial do negro. Os terreiros, para ele, era o laboratório de estudo desse "problema" que na ótica dele poder-se-ia atravancar a evolução da civilização brasileira. E nesse sentido, é pertinente o destaque-síntese de Ferretti (2006), referente à Introdução e o primeiro capítulo de os Africanos no Brasil,

[Rodrigues] trata de vários assuntos a cerca da inferioridade científica da raça negra, mostrando, ao mesmo tempo, a simpatia que o negro lhe inspira. Afirma que o problema social da raça negra foi sempre mal compreendido no país e que, por maiores sejam as nossas simpatias para com o negro, a raça

\footnotetext{
${ }^{3}$ Publicado no ano de 1896, este livro foi elogiado pela escrita e rigor etnográfico em resenha do notável sociólogo e antropólogo francês Marcel Mauss (1872 - 1950), sobrinho e parceiro intelectual do fundador da sociologia científica Émile Durkheim (1858 - 1917).

${ }^{4}$ Segundo informa Ferretti este livro "foi deixado na gráfica [por Nina Rodrigues] quando ele viajou para a França em 1906 e fazia parte de uma História da América Portuguesa, inacabada. O livro só foi publicado 30 anos após a sua morte." (op.cit, p. 55).
} 
negra no Brasil há que constituir um dos fatores de nossa inferioridade como povo [...]. Discute procedências africanas do negro no Brasil. Invoca Silvio Romero, ao comentar a vergonha de até agora não termos consagrado trabalhos aos estudos das línguas e das religiões africanas trazidas ao Brasil e argumentou que o negro deve ser considerado como objeto de ciência (FERRETTI, 2006, p.57-grifos meus).

Em outras palavras, era preciso aproximar, estabelecer contatos, observar de perto e examinar meticulosamente as coisas para explicar a relação entre raça e civilização - não como solução, mas como um problema.

Com aquela concepção arraigada em seu pensamento, é que o médico Nina Rodrigues, nos terreiros de candomblés, vai voltar seu olhar atento ao "transe extático", na possessão. Essa experiência que ele interpretou análogo a um "estado de sonambulismo provocado, com desdobramento e substituição da personalidade" propiciado pelo "fraco desenvolvimento intelectual" do negro".

Na tentativa de comprovar esta hipótese dele sobre o transe extático, Rodrigues vai fazer no gabinete dele, na universidade, experiência com voluntários de terreiros de candomblé, de hipnotismo, conforme citação de Silva (2000)

O animismo fetichista dos negros baianos, o primeiro estudo sobre fetiche no Brasil [foi] observado entre africanos e mestiços da religião iorubá, tendo [Nina Rodrigues] presenciado cultos originais e efetuadas experiencias de hipnotismo, em seu consultório ao Terreiro de Jesus, em frente à Faculdade [...]. (LIMA, apud SILVA, 2000, p.73).

É preciso acrescentar antes de terminar sobre a escolha de Rodrigues pelos terreiros de candomblés de língua yorubá na Bahia. Isso teve a ver com a predominância de terreiros de candomblé de origem yorubá localizados em Salvador, principalmente pelo fato de o contingente majoritário de africanos escravizados de descendência sudanesa ali introduzidos. E como mencionado anteriormente, ele se interessou especialmente pelo candomblé nagô, considerando consistir num modelo autêntico, a verdadeira religião fetichista. E para atestar isso ele introduz em os Africanos no Brasil

\footnotetext{
${ }^{5}$ A citação comentada de Márcio Goldman ajuda compreender melhor o pensamento de Rodrigues: "perda da personalidade terrestre do filho-de-santo que assumiria então a personalidade de seu orixá" [...]. A utilização do conceito de personalidade é sintomática. Com esse modelo - que curiosamente coincide com o modelo consciente dos informantes, bastando para isso que não se leve a sério demais a noção de personalidade que, no entanto, paradoxalmente, será a chave da explicação - Nina Rodrigues sustentará então, baseado em certas colocações da psiquiatria de Janet, que a possessão [...]. deste modo, é fenômeno semelhante às perturbações histéricas.
} 
a noção de sincretismo, para discutir a relação do culto fetichista com o catolicismo tanto simbólica quanto da participação de candomblecista nos cultos católicos. Na acepção Rodrigues a categoria sincretismo remete à ideia de "disfarce" ou "dissimulação", recurso utilizado pelos africanos para fugir às perseguições sofridas no âmbito da sociedade escravocrata e que fora eficaz para preservação dos cultos fetichistas. Em outras palavras, o sincretismo na definição de Rodrigues consistia na associação dos orixás com santos católicos que apontava para uma "ilusão de catequese", possibilitando explicar o advento da implantação de religiões africanas no Brasil e suas variações (FERETTI, 1995).

Subjacente à noção de sincretismo empregada por Rodrigues, pode se inferir por um lado, a ênfase na incapacidade intelectual do negro para assimilar a doutrina e dogmas da religião católica, não obstante a catequização e, por outro lado, estabelecer uma hierarquização entre as categorias de religiões africanas, considerando a presença embora minoritária de candomblés de caboclo e cultos bantos na Bahia e presente em outras regiões do país - por exemplo no Rio de Janeiro e Pernambuco como ele mencionou em Africanos no Brasil. Ao fazer isso, Rodrigo contribuiu para a legitimidade no campo religioso e na sociedade englobante dos terreiros jêje-nagô em detrimento a outros, que continuaram vulneráveis à perseguições policiais e acusação preconceituosa de "magia" e "feitiçaria".

Em síntese, os estudos sobre candomblés na Bahia Rodrigues reforçaram a imagem estereotipada e negativa da identidade do negro dentro e fora das fronteiras regionais da Bahia e, além disso, retirou dos ombros das elites escravocratas o peso da culpa pela condição marginal do negro na sociedade brasileira, ao atribuir à fatores equivocados de hierarquização racial, os entraves para modernização e progresso nacional, situando aí o "problema negro". Por fim, o modelo estabelecido por Nina Rodrigues, pela primorosa produção etnográfica dele, acabou sendo aceito acriticamente pelos seus discípulos e sucessores, embora discordantes das premissas racistas que nortearam a interpretação dele sobre o negro e a cultura negra. Como veremos adiante. 
Desde Nina Rodrigues, que faleceu em 1906, estudos sobre as religiões afrobrasileiras só foram retomados na década de 1930. O uso da categoria "raça" é abandonas a partir deste período em diante, sendo substituída pela expressão "cultura". Precedido pelo movimento de arte moderna instaurado em 1922, pode-se afirmar que nos anos trinta busca se consolidar a formação de um pensamento intelectual brasileiro voltado principalmente para interpretação do processo histórico de constituição da sociedade brasileira considerando a positividade das contribuições culturais de negros, brancos e índios na configuração da identidade nacional. Com efeito, a tese de doutorado do sociólogo pernambucano Gilberto Freyre (1900 - 1987), publicada no ano de 1933, Casa-Grande e Senzala em 1933 marcou a ruptura com a predominância das teorias racistas. É nesse contexto histórico que se inserem os escritos do intelectual alagoano Arthur Ramos de Araujo Pereira (1903-1949) e do intelectual baiano Edson de Souza Carneiro (1912-1972), sobre o negro a cultura afro-brasileira, conforme se segue.

Arthur Ramos era médico psiquiatra, psicanalista e psicólogo social, conhecido internacionalmente. O quadro teórico no qual ele embasou a abordagem dele sobre a cultura negra, entre outras referências, destaca-se a principalmente a teoria das categorias do pensamento humano proposta pelo filósofo e sociólogo francês, Lucien Levy Brühl (1857-1939), filiado à Escola Sociológica Francesa de Émile Durkheim (18581917) e a antropologia cultural norte-americana. Arthur Ramos estava interessado em seus estudos sobre o negro e a cultura na compreensão de "as representações coletivas" na "psiquê" do afrodescendente (RAMOS, 1988, p. 21-22), partindo do pressuposto de a mentalidade do afro-brasileiro ser imbuída por um tipo pensamento "pré-lógico", herdado culturalmente e suas origens (idem, 1988, p.22).

Esse entendimento se deixa entrever nas discussões em torno da noção de sincretismo empreendidas por Ramos nas páginas de $O$ negro brasileiro, onde se localiza diferenciação da noção de sincretismo no registro dele para a definição presente em Nina Rodrigues. Ramos repensou a ideia de sincretismo à luz do culturalismo americano, portanto com referência ao conceito de "aculturação". Expressão que descrevia o contato entre a cultura dos povos colonizadores com a dos colonizados e seus impactos na transformação ou desaparecimento dessas últimas pelas primeiras. Nesse registro, Ramos definiu sincretismo como processo de "simbiose" ou fusão das religiões africanas com o catolicismo que apontava naquela direção. Fenômeno que ele lembrou ocorrer 
historicamente desde o continente africano, tanto no contato dos "cultos fetichista entre si, quanto entre estes e o catolicismo" (RAMOS, 1988, p. 29; 116).

Ao redefinir o conceito, Ramos descreve o sincretismo das religiões africanas com o catolicismo no Brasil como um elemento positivo e que tendia apontar para superação da "mentalidade primitiva", isto é, "pré-lógica" e, portanto, do surgimento de um "pensamento novo" em direção, pode-se inferir, de uma lógica racional (RAMOS, 1988, p.114; 127).

Leitura da obra citada entre outros escritos de Ramos ou com referência ao ponto de vista dele, deixa entrever que embora ele parta do conceito de "cultura" para pensar a contribuição do negro na sociedade brasileira - tema em voga no seu tempo nacional, ele irá avançar substantivamente em relação aos pressupostos teóricos evolucionista que nortearam o pensamento de Nina Rodrigues. Conforme se evidencia na argumentação que ele apresenta para explicar o "problema do negro" na sociedade brasileira, e o fenômeno das religiões afro nas suas diferenças e diversidade. Um problema que não se restringiu exclusivamente ao esforço dele como "médicoetnógrafo", mas às limitações dos referenciais teóricos nos quais confiou. (DANTAS, 1982, p. 15-20).

\section{$X X X X$}

A abordagem culturalista também foi adotada pelo advogado e jornalista baiano Edison de Souza Carneiro (1912 - 1972) em seus estudos sobre religiões e "folklore" afro-brasileiros a partir dos anos 30. Entre as suas principais obras destaca-se sobre religião Candomblés da Bahia. Carneiro trilhou caminho semelhante ao de Nina Rodrigues, na pesquisa do repertório variado das religiões afro-brasileiras em Salvador, concordando com o primeiro sobre a distinção dos candomblés nagôs como modelo autêntico dos cultos fetichista africanos na Bahia. Diferentemente de Nina Rodrigues, porém, ele se interessou pelo estudo dos candomblés de referência banto, com um olhar menos preconceituoso para singularidade dessa modalidade e sem desqualificálos comparativamente com os terreiros jeje e nagô. (SILVA, 1993, p. 69-70).

Norteado pelo referencial do culturalismo, interpretação de Edison Carneiro sobre as religiões africanas se aproximaram das abordagens de Arthur Ramos. Ele 
concordava que as religiões afro-brasileiras consistiam em "vestígios de primitivismo" transplantado para Brasil e, portanto, admitia que o "sincretismo religioso" era um fator positivo para a evolução gradual da cultura das "classes atrasadas", fazendo alusão às populações afrodescendentes na Bahia (CARNEIRO, 1991, p. 94-98).

Ao discutir sobre o problema da "raça negra no Brasil", Edison Carneiro apresenta em seus escritos uma posição mais crítica referente à situação do negro na sociedade brasileira. Porém, ainda assim ele não consegue escapar à cilada das concepções evolucionista presentes também em Arthur Ramos, de estágios avançados de culturas em relação a outras e desse modo deixando insinuado que o negro era em "nível moral e intelectual" atrasado em relação ao branco (CARNEIRO, 1991, p. 25).

Portanto, o ponto de vista de Édison Carneiro assim como o de Arthur Ramos sobre o negro e as religiões afro-brasileiras no Brasil, no fundo se aproxima do olhar de Nina Rodrigues para a cultura afro-brasileira e os detentores desse legado, como bem evidencia a crítica da antropóloga Beatriz Góis Dantas - "nos anos trinta [...] a inferioridade biológica do negro devia ser repensada e substituída por outra, ou no mínimo camuflada, tornada menos explícita" (DANTAS, 1984, p.102).

Não há dúvida que estes estudos, assim como os de Nina Rodrigues reforçavam o preconceito contra o negro no Brasil e, por isso mesmo, suscita(r)am as críticas dos movimentos sociais negros.

E antes de encerrar esta seção é interessante acrescentar ainda a considerações do antropólogo Vagner Gonçalves da Silva na obra, O Antropólogo e sua magia (2000), chama atenção para assimetria de classe social e a questão identidade étnica subjacente ao campo de estudo das religiões afro-brasileiras no período contemplado acima. Em primeiro lugar ele observa que embora os pesquisadores e pesquisados fizessem parte da mesma "sociedade nacional", representavam dois grupos sociais contrastantes "os primeiros (elite formalmente instituídas) e os segundos (índios, negros populações rurais, minorias marginalizadas etc)" (SILVA, 1993, p.73). Nesse ponto, ele questiona a implicação disso na análise e interpretação dos pesquisadores referente ao objeto investigado.

Em segundo lugar, ele discorre sobre a pouca ou nenhuma visibilidade alcançada pelos pesquisadores negros, assim como a importância menor para as pesquisas deles. Ele cita os nomes de Manoel Quirino, Nunes Pereira e mesmo Edson Carneiro, 
argumentando que Manoel Quirino, antes de Nina Rodrigues, já pesquisava as religiões e a cultura afro-brasileira na Bahia, embora não tenha elaborado um registro "sistemático" como feito por Nina Rodrigues na época. (SILVA, 1993, p.74). Ressalta que pouco destaque foi dado ao que ele escreveu. Silva acrescenta que Arthur Ramos, mesmo tendo reunido artigo de Manuel Quirino, publicado em finais dos anos trinta "excluiu esse autor da 'linhagem nobre' dos estudos afro-brasileiros representado pelos Herdeiros da Escola de Nina Rodrigues" (SILVA, 1993, p.74). Outro pesquisador mencionado por ele foi Nunes Pereira, que, segundo Silva, escreveu a primeira etnografia sobre "o culto aos voduns jejes na Casa das Minas". (SILVA, idem).

Ao destacar estes dois pesquisadores negros e de origem humilde, Silva afirma que Quirino e Pereira possuíam uma longa vivência da cultura sobre a qual escreveram. Nunes Pereira, inclusive, era filho de uma iniciada na Casa das Minas. Diferentemente da experiência de Nina Rodrigues e Arthur Ramos como "médicos-etnógrafos". Além disso, enfatizou Silva, nem Quirino e Pereira, não se deixaram levar por quadros teóricos hegemônicos na época, e a singularidade dos escritos foi "valorizar a contribuição cultural dos negros na formação da sociedade nacional”. (SILVA, 1003, p. 74-75).

E concernente ao etnógrafo negro Edson Carneiro, Silva atenta para o fato de os estudos dele terem sido mais bem aceitos entre os estudiosos, não obstante valorizarem os cultos bantos, visto com desprezo em comparação com os iorubas. Entretanto, Silva faz a seguinte ressalva:

Embora Carneiro tivesse desenvolvido um trabalho de campo muito mais intenso do que o dos pesquisadores de sua época, inclusive de seu mestre Artur Ramos [...], e ter escrito inúmeras obras sobre o sobre outros aspectos da cultura brasileira, além do candomblé, teve sua inserção nos meios acadêmicos bastante restringida. (SILVA, 1993, p.75).

Por fim, Silva destaca que

Em vários momentos no desenvolvimento dos estudos afro-brasileiros (sobre religiosidade ou não), o uso da condição étnica de pesquisadores pesquisados foi alvo de críticas feitas por parte de intelectuais militantes, em geral negros, engajados em movimentos políticos de esquerda e de luta contra discriminação racial. (SILVA, 1993, p.76). 
Em síntese, ao revisitar os estudos das religiões afro-brasileiras no contexto histórico em tela como fizemos nesta seção, é possível apreender que a questão da desigualdade e discriminação étnico-racial pode ser detectada em dois níveis da leitura: o primeiro, com foco no registro dos estudiosos, com atenção para o quadro de abordagem com o qual eles estavam comprometidos e a implicação deles nas análises interpretativa da cultura; em segundo, atentar para a localidade social de origem dos pesquisadores e lugar étnico-racial de fala deles para uma leitura a contrapelo dos registros que produzem sobre o Outro. Essa provocação que Vagner Silva traz ao remontar ao passado trouxe para os dias de hoje.

\section{De afro a brasileiro}

Os estudos publicados pelo sociólogo francês Roger Bastide ${ }^{6}$ nos anos 1950 trouxeram uma ou visão do negro e a representação das religiões africanas no Brasil, rompendo com as interpretações culturalistas dos intelectuais dos anos trinta que, nas palavras de Monteiro (1978, p.11), "sofriam das limitações próprias de quadros teóricos comprometidos com uma orientação psicológica e, não raramente, marcados por um viez 'branco'”. No esforço de avançar em relação a esses estudos, Bastide conduziu os estudos dele inspirado na "sociologia em profundidade" de G.Gurvith e em diálogo com contribuições instrumentais teóricas de grandes pensadores como Émile Durkheim, Marcel Mauss, Max Weber, Maurice Halbwacs entre outros. As pesquisas sobre o negro e a cultura afro-brasileira que desenvolveu foram intensivas, prolongadas e com recorte temático variado (além das religiões, agremiações religiosas, movimentos sociais, clubes recreativos etc.). A partir de finais dos anos 1950 ganharam publicação os estudos $O$ Candomblé da Bahia - rito nagô (1958) e As Religiões Africanas no Brasil (1960) - que abordo nesse artigo. Essas obras apresentaram uma descrição interpretativa e densa das religiões africanas, que abriram as janelas para uma visão sociológica e antropológica da importância e do significado histórico, social e simbólico das religiões afro para os africanos da diáspora e seus descendentes neste lado do atlântico ${ }^{7}$.

\footnotetext{
${ }^{6}$ O sociólogo esteve no Brasil como professor colaborador da instalação do curso de Ciências Sociais na Universidade de São Paulo e depois de voltar para França, entre idas e vindas.

${ }^{7}$ Estudos dele sobre o negro no Brasil, abrangendo, além das religiões, as confrarias religiosas católicas, os reinados/congados, as produções artísticas, os movimentos sociais, os clubes recreativos, etc.
} 
Bastide era crítico às perspectivas culturalistas observando que elas abordavam a "cultura" como um sistema autônomo em relação à sociedade. Para Bastide, essa concepção levava ao equívoco de interpretações, perdendo-se de vista a dialética da cultura no contexto da sociedade global. Esse movimento que Bastide procurou evidenciar através da introdução do "método dialético" no estudo das religiões africana. (BASTIDE, 1973, p. XIV). Em segundo, pelos instrumentos analíticos, como o conceito de "aculturação", integrado a concepção de sincretismo associado a ideia "fusão" e "simbiose". Visando superar essa noção, ele utilizou o conceito de "interpenetração de civilizações". Conforme ressaltou o antropólogo Sérgio Ferretti:

Bastide critica e procura ultrapassar o conceito de aculturação. Considera que não são as civilizações que entram em contato, mas os homens. Não se pode estudar as civilizações separando-os das situações de contatos, daí a necessidade de encarar o encontro de civilizações ultrapassando a sociologia colonial, através de uma sociologia da profundidade. (FERRETTI, 1995, p.54).

Nos escritos de Bastide sobre as religiões africana apreende-se que a preocupação central dele residiu na problemática da "sobrevivência" e "metamorfose" dessas tradições e interligação com a identidade do negro na sociedade brasileira. Ele colocou em questão a condição das religiões afro-brasileiras instaladas no espaço urbano de capitais em processo de modernização e desenvolvimento industrial, considerando especialmente as capitais de São Paulo e Rio de Janeiro. Ele se empenhou no desenvolvimento de um trabalho comparativo do repertório variado de religiões africanas, no qual elegeu como referencial empírico de aferição os grupos iorubá (nagôs, jêjes, queto) localizados no nordeste brasileiro, com destaque especialmente para o Candomblé na Bahia.

Semelhante aos "médicos-etnógrafos", Bastide também considerou o Candomblé como a religião "autêntica" de matriz africana, onde se preservou a "memória coletiva" ancestral que possibilitou o estabelecimento de laços de sociabilidade e restauração da identidade pessoal e étnico-racial do africano e seus descendentes no Brasil (BASTIDE, 1971, p. 524 -525). Essa expressão conceitual (memória coletiva), apropriada de Maurice Halbwachs para explicar dialeticamente a estrutura do Candomblé, Bastide elucidou corresponder a "conjunto de imagens 
mentais ligados, de um lado, a mecanismo motores, os ritos [...] e, de outro, a estruturas morfológicas sociais (idem, p. 344).

Essa estrutura pode ser apreendida no livro O Candomblé da Bahia - rito nagô, no qual Bastide discorre sobre ao as noções de "participação" e "princípio de ruptura' (também traduzido por "cisão" ou "corte"). Categorias chave no quadro referencial teórico do estudioso, empregadas analiticamente na descrição da organização social, ritual e simbólica do Candomblé enquanto espaço do sagrado onde se estabelece, através da iniciação, a "comunhão entre indivíduos e divindades", como escreveu Bastide - "o próprio candomblé como grupo humano é uma imagem da sociedade divina. As relações que nele se tece entre os membros refletem as relações existentes entre os orixás" (BASTIDE, 1973, p. 242), complementando, "o indivíduo não repete os gestos dos deuses apenas no transe, da dança extática, mas também em sua vida cotidiana, em seu comportamento de todos os dias. Existe, é certo, ação e reação incessantes do natural sobre o cultural, do cultural sobre o natural" (BASTIDE, 1973, p 258). Bastide observou que essa estreita relação entre indivíduos e divindades refletia na característica da personalidade do indivíduo, mas não interferia na autonomia individual, explicando que há no indivíduo, de modo distinto, a presença do orixá ("santo" ou "encantado") e do "emi" ("um sopro"), assim, ao "possuirmos um orixá estamos refletindo simbolicamente o mundo mítico; ao possuir emi, somos donos de uma existência que nos é própria, somos um indivíduo. É o que chamamos de princípio de ruptura, que distingue na realidade ambiente certo número de compartimentos separados". (BASTIDE, 1973, p. 251). O "princípio de ruptura" ou "corte", é o que media o transitar do indivíduo em dois mundos: o candomblé, como pai, mãe, filho ou filha de santo; e no mundo profano, no desempenho dos papeis sociais na vida cotidiana, sem haver contradição ou gerar no indivíduo conflito psíquico ou de identidade pessoal.

Em síntese, Bastide buscou mostrar que o Candomblé é uma religião onde, como traduziu Márcio Goldman $(1985)^{8}$, “o ser humano é pensado como uma síntese complexa", isto é, retomando palavras de Bastitde, "os Orixás, os Exu e os erê existem fora de nós, constituindo o mundo divino, e ao mesmo tempo dentro de nós, constituindo o mundo divino e, ao mesmo tempo, dentro de nós, constituindo parte de

\footnotetext{
8 “A construção ritual da pessoa: a possessão no candomblé". Religião e Sociedade, 1985, p. 12(1):22-54.
} 
nossa estrutura íntima" (BASTIDE, 1973, p.262). Portanto, equivocado pensar que o Candomblé se reduz a um conjunto de gestos, "danças extáticas" ou ritos exteriores aos indivíduos, muito mais que isso, consiste em um sistema complexo de crenças incorporada no íntimo do iniciado e que se reflete no seu jeito de ser, agir e pensar, isto é, na sua visão de mundo e estilo de vida.

Na leitura de Ferretti (1995) o "princípio de cisão" foi um instrumental analítico que Bastide utilizou para também elucidar o fenômeno da interpenetração de civilizações, nas palavras dele o "princípio de cisão [em Bastide] aparece como uma características dos fenômenos aculturativos, agindo, sobretudo, nas famílias ligada ao candomblé nas classes, baixas das sociedades onde a influência da escola permaneceu confinada a alguns anos da primeira infância e nas comunidades onde os preconceitos de cor são mínimos" (FERRETTI, 1995, p. 57).

Em outra obra, As Religiões Africanas, o conceito de "princípio de cisão" é utilizado por Bastide para discutir as condições imposta a africanos e seus descendentes desde historicamente no contexto da sociedade brasileira. Ele apontou a existência de duas alternativas: por um lado o "enquistamento" e, por outro, a "integração" na sociedade global (BASTIDE, 1971, p. 389). Remontando ao período colonial, Bastide explicou que o "enquistamento" consistiu no relativo isolamento das comunidades negras no contexto da sociedade envolvente - e o exemplo que ele cita são as famílias tradicionais de candomblé; os terreiros onde se teceram relações de sociabilidade inclusivas e propiciaram a africanos e seus descendentes manter fortalecidas sua identidade pessoal e étnica. Por sua vez, a "integração" do negro na sociedade, implicava para o negro o afastamento, a negação e o abandono dos valores e crenças conectados à memória coletiva africana. Essa a condição que ele avaliava impor-se ao negro no sudeste brasileiro, principalmente nas grandes cidades como São Paulo e Rio de Janeiro, onde o processo de urbanização e de industrialização eram crescentes. Sendo este o desafio que ele considerava interpor à "sobrevivência" das religiões africanas nessas localidades geográficas do país.

Para Bastide era incerto que a "verdadeira religião" - considerando o Candomblé - tivesse chance de sobreviver naqueles contextos urbanos do Sudeste, distantes do seu "habitah natural" que seriam as regiões litorâneas do Nordeste onde ainda havia espaço para se manter um estilo de vida aos moldes tradicionais pré- 
capitalista industrial - conforme as críticas do antropólogo Peter Fry (1986, p. 38). Essa impossibilidade de "sobrevivência" da religião afro naquelas localidades era emblemática da tendência à perda referenciais próprio e, por conseguinte, a crise de identidade pessoal e étnica do negro e famílias negras no contexto das sociedades urbano-industriais (BASTIDE, 1971, p. 389 - 390). Na leitura de Paula Monteiro (1999), esse era um dos problemas que ela detectava na interpretação de Bastide sobre a situação do negro na sociedade brasileira, pois implicitamente o sociólogo da a entender que não restava outra saída para o negro afirmar sua identidade, senão o "equistamento", isto é, recolher-se em comunidades isoladas.

Não obstante deixar margem à críticas, os estudos de Bastides possibilitaram uma outra compreensão da situação do negro na sociedade brasileira, chamando atenção para o preconceito e a discriminação racial contra esse segmento populacional como um fator de raiz histórica vinculado ao processo mercantil de expansão colonial e escravização da força de trabalho humano entre as quais dos africanos no Brasil e as mazelas do desdobramento disto pós abolição na situação de marginalização e condição de vida do afro-brasileiro, portanto, a integração e proletarização dele na sociedade de classe.

$\mathrm{XX} X \mathrm{XX}$

A partir dos anos 1960 os estudos das religiões afro-brasileiras tomaram novo impulso. O interesse na etnografia da Macumba, Umbanda e Kardecismo localizadas nas regiões metropolitanas de São Paulo e Rio de Janeiro; assim como a investigação da religiões afro em localidade do nordeste brasileiro como Aracaju, propiciou o estabelecimento de uma revisão crítica dos escritos de Nina Rodrigues, Artur Ramos, Edison Carneiro e Roger Bastide - colocando em xeque ou mesmo refutando o "africanimo" e a ideia da "pureza nagô", convergente nesses estudiosos.

A começar pela tese de doutoramento do antropólogo Renato Ortiz defendida em 1970, na École de Haute Étude de Paris, sob a orientação do mestre Roger Bastide, publicada no Brasil, em 1991, com o título A morte branca do feiticeiro negro. Nesse estudo, resultado de pesquisas da Umbanda na capital de São Paulo, embora seguindo algumas pistas do orientador, Renato Ortiz divergiu da avaliação de Bastide que a 
Umbanda era uma "deturpação do Candomblé", questionando ainda a ideia de "pureza" do rito nagô. Ele argumentou com base em registros documentais e trabalho de campo que, ao contrário do entendimento tido pelo mestre, a Umbanda não era uma religião de matriz africana, mas brasileira - e, diga-se de passagem, observação que Bastide concordou. A Umbanda, descreveu Ortiz, consiste na síntese de um pensamento religioso brasileiro, oriundo da fusão do movimento duplo de "embranquecimento" da cultura negra articulada ao "empretecimento" da ideologia kardecista. (ORTIZ, 1991, p.47).

Essa observação está presente também no livro publicado em 1987, com o título sugestivo - Umbanda: uma religião brasileira, de autoria da pesquisadora Maria Helena Concone, originalmente tese de doutorado produzida no mesmo período do trabalho de Ortiz, defendida na Universidade de São Paulo. Semelhante ao registro de Ortiz ela escreveu que a Umbanda era uma religião brasileira e não afro-brasileira e seu processo de afirmação experimentou um duplo movimento: "arienização" e "negritude". (CONCONE, 1987, p.151).

De volta a Ortiz, ele acrescenta sobre a Umbanda que embora seja uma religião de possessão semelhante ao Candomblé, houve no começo o esforço de intelectuais mentores da sua fundação no sentido de rearticular símbolos e rito desse último segundo os códigos kardecista e cristãos. A Umbanda, portanto, afirma Ortiz, é uma modalidade de religião "sintética" e não sincrética.

Ortiz chama atenção para o contexto de surgimento da Umbanda, que se deu num momento em que se consolidava no Brasil um tipo de sociedade urbano-industrial e de classe. Esse acontecimento que na interpretação de Ortiz veio se refletir nos valores e modo dos intelectuais mentores da institucionalização da Umbanda pensar sua forma de organização burocrática e como orientar a prática ritual, tendo em perspectiva a aceitação dela e legitimação no seio da sociedade brasileira. E neste processo de reconhecimento, Ortiz destacou a fundação das Associações e Federações umbandistas, a produção de literatura "pseudocientífica", assim como a liderança e participação de pessoas brancas e de classe média como elementos de mediação significativos. (ORTIZ, 1991, p. 64; 182; 185). 
Concernente a este último destaque, a historiadora norte americana Diana Brow (1977) também observou nas pesquisas que realizava no Rio de Janeiro, a influência da participação de pessoas brancas na aceitação da Umbanda.

\section{$x X X X$}

\section{A dinâmica das religiões afro-brasileiras}

O trabalho etnográfico do mestrado de Beatriz Góis Dantas, publicado em 1988 com o título Vovó Nagô e Papai Branco: usos e abusos da África no Brasil, pode ser considerado um divisor de águas no campo dos estudos das religiões afro-brasileiras. Ela realizou pesquisa de campo nos terreiros de candomblés no município de Laranjeiras, localizado na zona açucareira de Sergipe. Com base nessas investigações de campo e análise dos dados ela conseguiu produzir um estudo bem fundamentado em contraposição aos precedentes, no sentido da desconstrução do discurso da "sobrevivência" ou "pedaços da África plantados em pleno coração do Brasil", associado à tese da "pureza nagô" - que nos argumentos da pesquisadora era reforçada nos estudos de Roger Bastide.

Dantas destacada em seus escritos que a retórica de "pureza" do rito nagô se encontrava presente nos tanto nos escritos de Nina Rodrigues, quanto de Arthur Ramos e Edison Carneiro. Essa distinção teve a ver com a etnografia de Nina Rodrigues que ao estabelecer essa diferença também favoreceu a legitimidade destes terreiros na Bahia, onde no passado o número de africanos escravizados de procedência sudanesa era majoritário, isso também refletiu na predominância local de terreiros dessa origem. Dantas buscou analisar as disputas internas ao campo das religiões afro-brasileiras e as vantagens daquela legitimação reforçada pelo "médico-etnógrafo" e seus desdobramentos posteriores para outras regiões do Nordeste - como Laranjeira. (DANTAS, 1988, p. 161; 2002, p. 96 - 97).

$\mathrm{Na}$ compreensão de Dantas essa inquietação é que estava por traz da mobilização do discurso de intelectuais na distinção dos grupos que eram predominantes no Nordeste, isto é, de referência na língua iorubá (jêjes, nagôs) pesquisados no Maranhão e Salvador, eleitos como modelo da "pureza" e 
"autenticidade" dos ritos "fetichistas" africanos transplantados para o Brasil. Estabelecendo-se, desse modo, uma certa aliança entre ciência e Estado em torno da conveniência ${ }^{9}$ para se manter a dominação social e o "controle da religiosidade do negro". (DANTAS, 1988, p. 164). Assim, querendo ou não, a leitura de Dantas evidencia, os intelectuais acabaram desempenhando um papel central no processo de legitimação social dos cultos nagôs em detrimento de outras modalidades de tradição afrobrasileira. Ou seja, aquelas consideradas "impuras” na interpretação de Nina Rodrigues, Artur Ramos e mesmo nos registros posteriores de Roger Bastide.

Dantas ressaltou que as conclusões apresentadas por aqueles pioneiros propagando a hierarquização do repertório das tradições afro brasileiras, exaltando a superioridade de determinado grupo em contraste com outros do mesmo campo, levou à discriminação persecutória de quais grupos deveriam ser poupados e quais outros poderiam ser proibidos pelos agentes de segurança pública do Estado, isto é, aqueles avaliados pelos médicos-etnógrafos como "verdadeira religião" e os outros com atestado de "magia", "feitiçaria" etc, Nas palavra de Dantas "os terreiros mais tradicionais objeto de estudo dos antropólogos centros de verdadeira religião aos quais eles emprestavam proteção conseguiu ficar a salvo da repressão um policial que incidia mais violentamente sobre os "impuros", não valorizados "( DANTAS, 1988, p. 192)

Com base no que pode aferir durante o processo de elaboração de sua etnografia, Dantas, argumentou que a noção de "pureza" acabou por ser empregada de modo ideológico e reificado nos estudos do campo das religiões afro-brasileiras (DANTAS, 1988, p.19); em grande parte, segundo ela, pelos pesquisadores confiarem cegamente na versão seus próprios informantes, muitas vezes influenciados por algum tipo de afinidade eletiva ${ }^{10}$. Dantas constatou isso a partir experiência etnográficas nos terreiros de Laranjeira, onde o observou que os cultos propalados nos escritos de Nina Rodrigues, Edison Carneiro e outros pesquisadores como modelo da "autenticidade da tradição" nagô, naquela localidade eram considerados pelos próprios praticantes do culto de maneira inversa - como uma tradição misturada. Reportando aos estudos da

\footnotetext{
${ }^{9}$ Estou usando o termo no sentido de Geórge Yúdice (2013).

${ }^{10}$ Como se sabe Nina Rodrigues tornou-se ogan (FERRETTI, 2006) e Roger Bastide também foi acolhido como (BASTIDE, 1973, p. XI|).
} 
identidade étnica da antropóloga Manuela Carneiro da Cunha (1985), Dantas argumentou o seguinte:

[...] a continuidade cultural e a propalada fidelidade é um legado original - tanto nosso terreno de Sergipe como os da Bahia se dizem descendentes dos nagô - não dão conta da "pureza". Aliás, os estudos sobre etnicidade - e os terreiros se assemelham muito a micro-etnias - tem mostrado sobejamente que a cultura não é simplesmente uma bagagem que a sociedade carrega consigo e conserva como todo, não é algo acabado, mas algo que que se recorta de diferentes modos para afirmar a identidade e garantir interesses, sendo constantemente reinventada e investido de novos significados. (DANTAS, [b], 1982, p.17)

Essa argumentação de Beatriz Góis Dantas encontrou ressonância nos estudos que vieram depois, pela pertinência da crítica e as pistas deixada para o campo mais ampliado das tradições culturais afro-brasileiras - sobretudo por apontar para questões relacionadas à manipulação da cultura afro-brasileira como "recurso" pensado de acordo as conveniências e interesses variados no contexto da sociedade global.

$X X X X$

Os estudos do antropólogo Vagner Silva discutem a inserção do candomblé na metrópole de São Paulo, apontando a dinâmica cultural dessa tradição no contexto local. Silva não opera com a noção de sincretismo, categoria chave na literatura clássica do campo de estudo das tradições afro-brasileira, mas a partir de um aporte teórico das antropologias estrutural e hermenêutica com sabe no qual procurou dedicar seus estudos ao tema da dialogia cultural da religião afro no contexto da capital paulista. Silva procurou demonstrar em seus estudos que a instalação do Candomblé no espaço geográfico da metrópole paulistana implicou a negociação e diálogo com outras referências religiosas - principalmente a Umbanda.

No artigo "Esquinas do sagrado: usos religiosos do espaço do sagrado" (1996), ao discutir o processo de instalação do Candomblé em São Paulo, Vagner Silva descreveu a sequência: primeira fase rito angola; segunda fase rito fã; terceira fase rito queto; quarta fase rito queto "reafricanizado". (SILVA, 1996, p.94). Silva observou que uma vez instalada localmente, o processo de expansão do Candomblé pela malha metropolitana de São Paulo ocorreu, não raramente, com a migração de sacerdotes da Umbanda para 
a religião afro; exemplificado por ele mencionando o nome yalorixá Mãe-Silvia - mãede-santo reconhecida e referência forte do Candomblé em São Paulo (SILVA, 1996, p.93).

De acordo com a abordagem teórica da dinâmica cultural proposta por Marshal Sahlins (1990), Silva chamou atenção para os rearranjos e modificações por que passou o Candomblé ao se instalar no contexto metropolitano de São Paulo e se afirmar no campo religioso plural da cidade, compreendendo essa dinâmica sob a perspectiva da reinvenção da tradição. Silva destacou nos anos que se seguiram o movimento de "reafricanização" do Candomblé em São Paulo, configurado pela ida de sacerdotes para o continente africano, em busca de maior conhecimento sobre o culto aos orixás. $\mathrm{Na}$ leitura de Silva, essa experiência agregava prestígio e reforçava a autoridade da mãe ou pai de santo e, por extensão, o terreiro sob a liderança sacerdotal dele.

Nesse sentido, Silva observou que ao longo do tempo o candomblé acabou conquistando legitimidade junto alguns setores da sociedade paulistana (incluindo pessoas brancas e da classe média); e atraindo adeptos de outras religiões que optaram pela experiência da "iniciação" no culto dos orixás. Entretanto, acrescentou o antropólogo, é certo também que novos desafios surgiram para o Candomblé, inserido no contexto do "mercado religioso" competitivo e plural, que exigiu criatividade na reinvenção ou recriação da tradição, orientada de acordo com cosmologia da religião, mediante jogo de búzios e consulta aos orixás. Rituais que precederam as ações e escolhas de mães e pais-de-santo dos elementos adaptados ou incorporados no atendimento às necessidades emergentes, sintetizando a descrição de Silva (1996): convites impressos de divulgação da "Festa de Santo", fixado em paredes e muros pela cidade; despacho para Exu feito na beira do asfalto, em meio ao movimento de automóveis; diminuição do tempo de recolhimento de iniciantes; utilização navalhas descartáveis devido ao risco de contaminação pela AIDS, entre outros exemplos.

Ao discutir essas modificações, entre outras, que ocorreram no candomblé na metrópole de São Paulo - seja para afirmar-se como religião, seja para garantir espaços próprios - o que Silva evidencia em seus estudos que a reinvenção do candomblé teve em perspectiva atrair uma clientela socialmente heterogênea - porém isso não admite a interpretação de um processo de esvaziamento do significado étnico-racial religiões afros para afirmação identitária do negro no Brasil. Incluindo, portanto, os candomblés 
banto, que também se inseriram nos processos de "reafricanização" e hoje se afirmam na capital mineira em diálogo com a diversidade da cultura afro e movimentos negros da cidade. (CAPONE e MORAIS, 2020).

\section{Considerações}

A diversidade das formas de expressões da cultura africana recriada em solo brasileiro na longa duração, é um tema que desde o século XIX intelectuais nacionais e estrangeiros se interessaram pelo estudo com intuito invariavelmente de explicar a problemática identitária e do desenvolvimento sociocultural do país. Esse foi o ponto de partida deste artigo para discutir a temática da "desigualdade e discriminação étnicoracial" - expressão que se configura em duas faces de uma mesma moeda, isto é, a exclusão social de indivíduos e grupos humanos. Essa experiência que marca a história das populações afrodescendentes, cujos antepassados vivenciaram a violência da exploração de suas energias e mão de obra, submetidos à força ao trabalho escravizado e aos maus tratos que ferem a dignidade e o respeito à vida humana. Porém, mantiveram-se resistentes sem perder a coragem do enfrentamento da realidade com os meios possíveis para preservar uma memória ancestral, não obstante a perseguição das forças opressoras do poder.

As religiões afro-brasileiras lócus dessa "memória coletiva", como salienta-se em estudo abordado nesse artigo. Elas que no passado eram proibidas por lei constitucional e demonizadas pela igreja católica e nos dias de hoje, mesmo com mudança dessas leis, as religiões afro-brasileiras continuam sendo alvo de intolerância - essa atitude de discriminação étnico-racial, manifesta do "racismo estrutural" (ALMEIDA, 2020).

Esse processo de exclusão social se evidencia nos estudos sobre as religiões denominadas na literatura de finais do XIX e primeiro quartel do século $X X$, como "animismo fetichistas", "religiões fetichistas". Como vimos, o interesse no estudo delas pelos "médicos-etnógrafos" era, sobretudo, comprovar o "problema do negro" para o futuro do país - como enunciou Nina Rodrigues e insinuado nos escritos de Arthur Ramos e Edison Carneiro. 
$\mathrm{Na}$ crítica a esses intelectuais e à revisão dos pressupostos deles, apontam para "sobrevivência" ameaçada das religiões afro-brasileiras com processo de modernização e industrialização do país, destacando a importância delas para afirmação da identidade negra - como se apreende nos estudos de Bastide. É também nesse sociólogo que a exclusão social do negro (o preconceito e a discriminação racial) foi tema da preocupação e colocado em discussão.

A dinâmica cultural das religiões afro-brasileiras discutidas na última seção do artigo é sugestiva dos caminhos trilhados pelo povo-de-santo para preservação desse legado ancestral que é referência sagrada e simbólica da identidade negra.

Por fim, é preciso registrar que o volume de estudos sobre as religiões afrobrasileiras é abrangente (candomblés, batuque, xangô, umbanda entre outras variações), bem como das manifestações afro-brasileiras (reinados-congadas, maracatus, afoxés etc.). No conjunto, estes estudos oferecem elementos para uma reflexão crítica sobre discursos e imagens construídas dessas expressões afrodiaspóricas da diversidade cultural brasileira e ainda, de maneira associada, o processo de exclusão e subalternização do negro no Brasil. Isso que procurei fazer ao selecionar alguns estudos sobre religiões afro-brasileiras com intuito de contribuir para reflexão da temática "desigualdade e discriminação étnico-racial".

\section{Referências}

AMARAL, Rita 1996. "A festa de candomblé e sua relevância para o estuo do candomblé e do estilo de vida do povo-de-santo". In: Lima, Tânia (org.) - Sincretismo religioso - o ritual afro. Recife: Massangana (Anais do IV Congresso afro-brasileiro, vol.4)

ALMEIDA, Sílvio Luiz de. Racismo estrutural. São Paulo: Sueli Carneiro Editora Jandaina, 2020.

BASTIDE Roger. Estudos afro-brasileiros. São Paulo: Perspectiva, 1973.

BASTIDE, Roger O Candomblé da Bahia - rito nagô. São Paulo: Cia. Editora Nacional, [1958] 1978.

BASTIDE, Roger. As Religiões Africanas no Brasil - rito nagô. São Paulo: Livraria. Pioneira/EDUSP, [1960] 1971.

BIRMAN, Patrícia. Feitiço carrego e olho grande, os males do Brasil são: estudo de um centro umbandista numa favela do Rio de Janeiro. Dissertação de Mestrado, Programa de PósGraduação em Antropologia Social do Museu Nacional. Rio de Janeiro, 1980.

BROW, Diana. "Umbanda e classes sociais". In: Religião e Sociedade, Rio de Janeiro, $1977,18(2)$, p.63-74. 
CAPONE, Stefania e MORAIS, Mariana Ramos de. Afro-patrimônio no plural: a mistura no candomblé como valor excepcional. In: Vivência: Revista de Antropologia. v. 1, n 55 (jan/jun de 2020). Natal: UFRN/DAN/PPGAS, 2020, p.18-35. Link https://periodicos.ufrn.br/vivencia/issue/view/1055/567

CARNEIRO, Édison. Candomblés da Bahia. Rio de Janeiro/São Paulo: Editorial Andes, [1954]1978.

CARNEIRO, Édison. Religiões negras/negros bantos. Rio de Janeiro: Civilização Brasileira, 1981.

CONCONE, Maria H. Vilas Boas. Umbanda: uma religião brasileira. São Paulo: FFLCH/USP (Coleção Religião e Sociedade Brasileira 4), 1987.

COSTA, Joaze Bernardino; TORRES, Nelson Maldonado; GROSFOGUEL, Ramón (orgs). Decolonialidade e pensamento afrodiaspórico. Belo Horizonte: Autêntica, 2019 (Coleção Cultura Negra e Identidades)

CUNHA, Manuela Carneiro da. Negros estrangeiros: os escravos libertos e sua volta à África. São Paulo: Brasiliense, 1985.

DANTAS Beatriz Góis. Vovó Nagô e Papai Branco: usos e abusos da África no Brasil. Rio de Janeiro: Graal, 1988.

DANTAS, Beatriz Góis. "Nanã de Aracaju: trajetória de uma mãe plural”. In: SILVA, Vagner Gonçalves (org.). Caminhos da alma: memória afro-brasileira. São Paulo: Summus, 2002.

DANTAS, Beatriz Góis. "Repensando a pureza nagô". Religião e Sociedade, São Paulo, Cortez/Tempo e Presença, n.8, 1982.

FERRETTI, Sérgio F. "Nina Rodrigues e a religião dos Orixás". Gazeta Médica da Bahia;76(Suplemento 2):54-59. 2006.

FERRETTI, Sérgio. Repensando o Sincretismo: estudo sobre a Casa das Minas. São Paulo: EdUSP, 1995.

FREIRY, Gilberto. Casa-Grande e Senzala: formação da família brasileira sob o regime da economia patriarcal. São Paulo: Círculo do Livro (Livraria José Olympio Editora S.A.), 1933.

FRY, Peter. "Feijoada e soul food". In: Ensaios de opinião, n. 4, São Paulo, 1986.

FRY, Peter. "Manchster, século XIX e São Paulo, século XX - dois movimentos religiosos. (mímio), 1977.

GEERTZ, Clifford. A interpretação das Culturas. Rio de Janeiro: Zahar, 1978.

GOLDMAN, Márcio. "A construção ritual a pessoa: a possessão no Candomblé. In: Religião e Sociedade, Rio de Janeiro, ISER/CER, 1985, 12/1. Link http://www.gmbahia.ufba.br/index.php/gmbahia/article/view/307/298

MONTEIRO, Duglas T. "Roger Bastide: religião e ideologia”. In: Rio de Janeiro: Civilização Brasileira, Religião e Sociedade, n. 3, 1978, 11-24.

MORAIS, Mariana Ramos de. De religião a cultura, de cultura a religião: travessias afroreligiosas no espaço público. Belo Horizonte: PUC- Minas, 2018.

ORTIZ, Renato. A morte branca do feiticeiro negro. São Paulo: Brasiliense, 1991.

RAMOS, Arthur. Introdução à Psicologia Social. São Paulo: Casa do Psicólogo: Florianópolis, SC: Universidade Federal de Santa Catarina: Brasília, DF: Conselho Federal de Psicologia, 2003 (Coleção clássicos da psicologia brasileira).

RAMOS, Arthur. O negro brasileiro. Recife: Fundação Joaquim Nabuco: Editora Massagana, 1988. 
RODRIGUES, Nina. O animismo fetichista dos negros bahianos. Rio de Janeiro: Civilização Brasileira, 1935.

RODRIGUES, Nina. Os africanos no Brasil. São Paulo: Editora Nacional, 1977.

SAHLINS, Marshal. Ilhas de História. Rio de Janeiro, 1990.

SCHWARCZ, Lilia M. O espetáculo das raças: cientistas, instituições e questão racial no Brasil 1870-1930. São Paulo: Companhia das Letras, 1993.

SILVA, Rubens Alves da. "A propósito dos 500 anos: saudações a Oxalá e ao Senhor do Bonfim no sertão de Minas Gerais". In: Revista Cadernos de Campo, n. 11, 2003, p. 69-85.

SILVA, Rubens Alves da. Negros católicos ou catolicismo negro?: um estudo sobre a construção da identidade negra no congado mineiro. Belo Horizonte: Nandyala, 2010 (Coleção Repensando África, V.6).

SILVA, Vagner G. "As esquinas sagradas: o candomblé e o uso religioso da cidade". In: Magnani, José G. C. Na metrópole: textos de Antropologia Urbana. São Paulo: EdUSP,

SILVA, Vagner G. "O terreiro e a cidade nas etnografias afro-brasileiras". In. Revista de Antropologia. Dpto de Antropologia da Faculdade de Filosofia, Letras e Ciências Humanas da Universidade de São Paulo, 1993.

SILVA, Vagner G. da. $O$ antropólogo e sua magia: trabalho de campo e texto etnográfica nas pesquisas antropológicas sobre as religiões afro-brasileiras. São Paulo: EdUSP, 2000.

SILVA, Vagner G. O candomblé na cidade: tradição e renovação. Dissertação de Mestrado, FFLCH/USP - Programa de Pós-Graduação em antropologia Social, 1992.

SILVA, Vagner G. Orixás da metrópole. Petrópolis: Vozes, 2000.

SOUZA, Ricardo Luiz de. Identidade nacional e modernidade brasileira: o diálogo entre Sílvio Romero, Euclides da Cunha, Câmara Cascudo e Gilberto Freyre. Belo Horizonte: Autêntica, 2007.

STOCKING Jr., George W. A formação da antropologia americana, 1883-1911: antologia/Franz Boas. Rio de Janeiro: Contraponto: Editora UFRJ, 2004.

YÚDICE, George Yúdice. A conveniência da cultura: usos da cultura na era global. Belo Horizonte: Editora da UFMG, 2013. 